\title{
DIGITAL TRANSFORMATION OF VALUE CREATION PROCESSES IN TRADITIONAL INDUSTRIES: CASE STUDY OF POLISH HEALTH RESORT ENTERPRISES
}

\author{
Alina KOZARKIEWICZ ${ }^{1 *}$, Agnieszka KABALSKA ${ }^{2}$ \\ ${ }^{1}$ AGH University of Science and Technology, Faculty of Management, Department of Organisational \\ Management, Human Resources and Economic Law; akozarki@zarz.agh.edu.pl, ORCID: 0000-0002-0683-3148 \\ ${ }^{2}$ AGH University of Science and Technology, Faculty of Management, Department of Organisational \\ Management, Human Resources and Economic Law; akabalska@zarz.agh.edu.pl, \\ ORCID: 0000-0002-9646-3469 \\ * Correspondence author
}

Purpose: The main aim is to analyse the influence of DT on traditional industries, here: health resort enterprises in Poland. They are mostly based on tangible resources and customers of deficient digital competences. The research leads to the identification of the scope and the trends in the DT of this particular sector.

Design/methodology/approach: The research combined two approaches - the first was based on quantitative research and questionnaire as a data collecting method, and the second was based on netographic research and generic content analysis.

Findings: In terms of DT, the enterprises use various strategies, they use digital resources, attempt to acquire customer's recommendations, as well as try to establish customer-centric innovations through involving customers in co-creation processes.

Research limitations/implications: The research implication for management studies is the recognition and presentation of the heterogeneity of approaches towards DT of the firms functioning in a traditional, tangible-resources-based sector. The role of digital solutions in value creation processes in such a peculiar sector was delineated. The major limitation was the small sample size and restrained generalization in conducted content analysis.

Practical implications: The practical implication from a managerial perspective is to provide the basis for evaluation of prospects related to the adopted approach to the usage of different e-platforms in creating value and developing and sustaining relationships with customers.

Originality/value: The article responds to the challenges related to DT and its timeliness. The paper's value results from its topicality. It could serve as an inspiration for both science (the role of DT in value creation) and practice (sector's evolution towards digital communication channels).

Keywords: digital transformation, value creation, health resort enterprise, traditional industry.

Category of the paper: Research paper. 


\section{Introduction}

There is a significant volume of challenges for contemporary organizations, such as the rapid technology development, social or demographic changes, as well as new political forces

and instabilities. However, among all these alterations one seems to be worth studying more deeply - digital transformation. According to many researchers, it is imperative for these companies that strive for sustainable competitive position and economic success (Berman, 2012; Vial, 2019; Warner, and Wagner, 2019). Digital transformation (DT) could be understood as a process that aims to improve an entity by triggering significant changes to its properties through combinations of information, computing, communication, and connectivity technologies (Vial, 2019, p. 121). Nowadays, DT offers an interesting research area - oriented towards its technical, social and economic impact.

The aim of this paper is to analyse the influence of DT on traditional industries, with a long history, primarily based on tangible resources, and moreover, oriented towards customers who are rather slow in following new IT and mobile solutions. Among sectors meeting the criteria described above, there is one particularly interesting - health resort sector in Poland. The analysis presented in this paper is directed towards the identification of the scope and the trends in the DT of this peculiar sector. The research comprises two different approaches the first is based on a questionnaire and quantitative research, the second is based on netographic research and content analysis.

\section{Digital transformation of traditional sectors}

As it was indicated above, DT is based on the use of new digital technologies (social media, mobile, analytics or embedded devices) to enable major business improvements such as enhancing customer's experience, streamlining operations, or creating new business models (Vial, 2019). Most frequently digital technologies are oriented towards efficiency improvements, however, they also offer better connectivity and automatization. Due to their application, there are changes in customers' behaviour or expectations; as customers have access to information and communication, they become active participants in a dialogue between an organization and its stakeholders. Moreover, the technologies facilitate the alterations of existing products and services to create new forms of offerings, as well as new business models (Warner, and Wagner, 2019).

DT has a very broad context and it concerns all levels: from the whole economy, entire sectors, through businesses and non-profit organizations, to teams and individuals. It concerns both start-ups and modern industries as well as very traditional sectors and large corporations. 
There are results of prior research conducted in particular sectors or industries, such as the hospitality industry (Leung et al., 2015), healthcare (Sebastian et al., 2017) or fashion (Bertola, and Teunissen, 2018). The sector analysed in this paper was chosen intentionally as it has an interesting characteristic: it has undergone significant changes in the recent years - from very traditional, consisting of state-owned or state-supported enterprises, based on exploitation and usage of natural resources, towards more innovative and market-oriented businesses, trying to attract younger customers as well as Polish and foreign tourist. This is why it appears important to study the scope, trends, and courses of DT in such a particular context.

\section{Research methodology}

The research process was composed of two stages. The first comprised quantitative research, based on survey strategy. The questionnaire was forwarded to 135 Polish health resort enterprises that were selected deliberately - they were located in one of the 45 resort towns in Poland and offered a sanatorium treatment. The selection of research objects comprised two stages: in the first stage, the database featuring resorts with treatment contracts (signed with Polish financing entity) was created. Next, exclusively the facilities listed in the Register of Health Care Entities were chosen for further considerations. Ultimately, 48 health resort enterprises responded to the invitation and participated in the study.

The survey featured two major sections, and in the following article merely the results obtained from the second part are presented. The first part was regarding the characteristics of the health resort enterprises and comprehended close-ended questions referring to key components of the Business Model Canvas (Osterwalder, and Pigneur, 2010). The second, more extensive part, included questions that covered factors and conditions reflecting the peculiarities of health resort enterprises. Questions were classified into five major categories, likewise, pertaining to the main components of the BMC. In this survey's section, a 5-point scale based on R. Likert's scale was utilized to measure respondents' opinions about the importance of the particular factors ${ }^{1}$.

The second stage of the research process was based on netographic research. The analysis was linked to the research of G. Remane and co-authors (2017, p. 41), demonstrating that the transformation of traditional industries was driven by new opportunities for collecting and exploiting data, the connectivity of products, infrastructure, companies and customers, and the ever-expanding capability of components or systems to make autonomous decisions.

\footnotetext{
${ }^{1}$ In the paper authors acknowledged E. O'Sullivan's and G. Rassel's (1995, pp. 340-341) point of view, that by summing the numbers assigned to the category of answers to each item, the measurements are treated as if they were intervals. Thus, the examined factors were ordered from the most (5) to the least (1) significant. Three categories of the significance were distinguished, i.e. factors of low $(1.0<\mathrm{x} \leq 2.0)$, medium $(2.0<\mathrm{x} \leq 4.0)$ and of the major importance $(4.0<\mathrm{x} \leq 5.0)$.
} 
Moreover, the inspiration for this part of the research were the results of the empirical study, indicating the growing importance of new technologies in the sector of Polish health resort enterprises. The role of websites (e.g. of resort enterprises, resort alliances, tourist bureaus, websites dedicated to tourism and recreation) and social media (e.g. Facebook, Instagram, Twitter), launched brand-new territory for creating value and developing new competences.

\section{DT of health resort enterprises - the results of survey research}

The analysis of the results of empirical research enabled indicating the premises of health resort enterprises where the impact of new technologies on the operations is particularly important. It includes Customer Segments, i.e. customers' motivations and funding sources as well as communication and customer relations. Table 1 features the presentation of customer segments of health resorts in Poland in terms of the customers' motivations for choosing the offer and the funding sources, as well as the enterprises' approaches to communicate with their customers.

Table 1.

Basic statistics for the category of Customer Segments

\begin{tabular}{|c|c|c|c|c|c|c|c|}
\hline Variable (factor) & $\begin{array}{c}\text { Arithmetic } \\
\text { mean }\end{array}$ & Mode & Median & Range & Variance & $\begin{array}{l}\text { Standard } \\
\text { deviation }\end{array}$ & $\begin{array}{l}\text { Coeff. of } \\
\text { variation }\end{array}$ \\
\hline \multicolumn{8}{|c|}{ Customers' motivations and funding sources } \\
\hline $\begin{array}{l}\text { Patients financed by National } \\
\text { Health Fund (NFZ) or Social } \\
\text { Insurance Institution (ZUS) }\end{array}$ & 4.22 & 5.0 & 4.50 & 2 & 0.41 & 0.64 & 0.15 \\
\hline Commercial patients (customers) & 4.21 & 5.0 & 4.0 & 3 & 0.63 & 0.79 & 0.19 \\
\hline $\begin{array}{l}\text { Patients whose stays are co-financed } \\
\text { e.g. by NFZ or PFRON }\end{array}$ & 3.77 & 4.0 & 4.0 & 4 & 1.58 & 1.26 & 0.33 \\
\hline Tourists (from Poland) & 3.56 & 4.0 & 4.0 & 4 & 1.74 & 1.43 & 0.37 \\
\hline Families & 3.02 & 3.0 & 3.0 & 4 & 1.60 & 1.26 & 0.41 \\
\hline Foreigners (patients) & 2.67 & 1.0 & 2.5 & 4 & 2.06 & 1.43 & 0.53 \\
\hline Foreigners (tourists) & 2.27 & 1.0 & 2.0 & 4 & 1.86 & 1.36 & 0.59 \\
\hline \multicolumn{8}{|c|}{ Communication and customer relations } \\
\hline $\begin{array}{l}\text { Sanatorium referral (from NFZ, } \\
\text { ZUS, PFRON) }\end{array}$ & 4.50 & 5.0 & 5.0 & 3 & 0.42 & 0.65 & 0.14 \\
\hline $\begin{array}{l}\text { Website, where the offer is } \\
\text { presented and advertised }\end{array}$ & 4.29 & 5.0 & 4.0 & 4 & 0.72 & 0.84 & 0.19 \\
\hline Customer survey & 3.94 & 4.0 & 4.0 & 3 & 0.78 & 0.88 & 0.22 \\
\hline Profiles in social media & 3.44 & 4.0 & 4.0 & 4 & 1.32 & 1.15 & 0.33 \\
\hline $\begin{array}{l}\text { Participation in fairs, conferences, } \\
\text { or symposiums }\end{array}$ & 2.92 & 3.0 & 3.0 & 4 & 1.57 & 1.25 & 0.42 \\
\hline $\begin{array}{l}\text { Offer advertising in the media, } \\
\text { e.g. in newspapers }\end{array}$ & 2.83 & 4.0 & 3.0 & 4 & 1.76 & 1.33 & 0.47 \\
\hline $\begin{array}{l}\text { Advertising balneological products } \\
\text { in the media }\end{array}$ & 2.02 & 1.0 & 1.5 & 4 & 1.68 & 1.30 & 0.64 \\
\hline
\end{tabular}

Source: Authors' evaluation.

The empirical results pertaining to the customers' motivations and funding sources indicated that despite considering financed patients as the most important customer segment, the role of commercial patients (customers) is just as significant. The occurrence of another, 
non-traditional customer segments, e.g. tourists or foreigners (patients and/or tourists) also corresponds with this statement. It should be emphasized that the health resort's website appears to be an excellent tool for introducing and presenting the company's offer (e.g. different variants with different prices, additional sanatorium or spa services, etc.) as well as communicating with customers. The significance of customer surveys in maintaining customer relations as well as in co-creating value might take a different form for the contemporary resort business nowadays, customers have the opportunity to provide their feedback via reviews on social media or tourism-dedicated websites. According to the research results on the consequences of social media for the travel sector by S. Scott and W. Orlikowski (2010, p. 5), for certain tourism and hospitality enterprises, online reviews result in the difference between profit and loss, surviving a season or deciding to close down.

The role of the company's website is reflected in the responses to communication and customer relations. According to the research on the utility of websites of resort enterprises in Poland, A. Szromek and S. Pytel (2014, p. 278), stated that the majority of enterprises react rather quickly to customer's inquiries - nearly $75 \%$ of responses are coming within the first two days of making inquiries. It could be assumed that the response rate is higher nowadays. Managers who participated in the empirical study acknowledged the social media presence as a better way of interacting with customers in comparison with traditional advertising or even participating in promotional events (e.g. conferences or trade fairs).

\section{DT in creating value - the results of netographic research}

The results of the empirical research discussed above were the authors' starting point for further analysis. The netographic research of 48 enterprises was conducted, exploring websites and online shops, companies' profiles in various social media, blogs, and the offer presentation on other websites (e.g. referring to recreation).

\section{The websites' analysis}

The health resort enterprise's website proved to be a keystone in the value creation process - according to the conducted netographic research, 100\% of health resort businesses have a website, however, the information extent varies significantly. The four major categories (types) of health resort websites and their content proposed by authors are presented in Figure 1. What should be noted is that, based on the analysis of health resort websites and regardless of the level of website advancement, all enterprises (100\%) enable reservation via e-mail. 
A traditionalist approach is represented by health resort companies $(25 \%$ of enterprises from research sample) that observed the serious technological changes in the sector and responded to them by creating simple, non-complicated websites, where the quintessential information (e.g. offer description, contact numbers, e-mail addresses and photo gallery) are presented. Digital Newcomer and Connector are interjacent approaches to website development - Digital Newcomer offers an uncomplicated website but there is a contact form (or slide bar), which customers can easily complete when making an offer inquiry. A Connector represents the more technologically-developed website, where automated reservation form or system is proposed to simplify the process of customizing the offer; the common practice is placing the button-link to Google Maps where customers could plan their route in advance. Interestingly, the majority $(30 \%)$ of websites could be described as well-developed, user-friendly multisided platforms where modern solutions are applied (e.g. virtual walk-through, vlogs, interactive maps of touristic attractions, immersive video, or live chat with customer service employee).
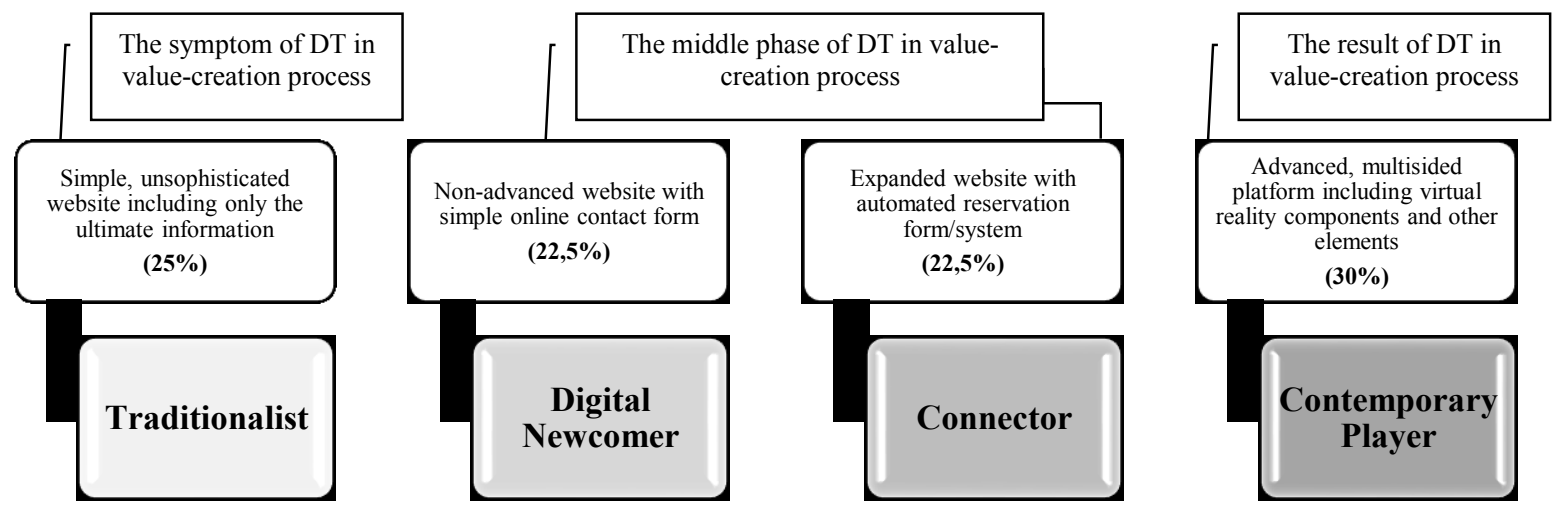

Figure 1. The categories of health resorts' websites and the characteristics of their content. Source: Authors' evaluation.

The analysis of netographic sources allowed indicating common paths in the digital valuecreation process. Health resort enterprises eagerly (28\%) publish customers' reviews in order to accentuate their competitive advantage (e.g. friendly staff, comfortable rooms, quality treatments and the variety of extracurricular activities). A subsequent, interesting form of innovation in the value-creating process is a newsletter, where signed recipients have the option of receiving treatments at lower prices or are invited to various events. The newsletter is offered by $20 \%$ of health resort enterprises which were included in the study.

Online shops, offering balneological products are other indicators of technological development in the investigated sector. In the following study, only 5 health resort enterprises produce balneological products (e.g. cosmetics, bottled water, etc.). However, it should be underlined that solely three of them have an e-shop, where customers are able to purchase the product - two health resort businesses created a dedicated website, where the offer is presented, but there is no possibility of purchase. This is quite surprising, especially in the era of online shopping, which is becoming increasingly popular; moreover, having a unique offer builds a significant competitive advantage. 


\section{Social media profiles}

Despite the foregoing research on the utilization of social media for public health (e.g. Paul, and Dredze, 2011) or hotel industry (e.g. Leung, Bai, and Stahura, 2015), the investigation on social media platforms for health resort enterprises still offers an interesting potential. Netographic research allowed observing that resorts eagerly seek to communicate with and engage their customers through social media - primarily Facebook, where $78 \%$ of enterprises from the research sample have an active and up-to-date profile. $20 \%$ of health resort businesses have a YouTube channel, followed by a Twitter account (18\%); an Instagram profile is being updated only by $10 \%$ of health resort enterprises. The analysis of the resorts' Facebook profiles demonstrated the occurring phenomena of customer's involvement in value-creation processes by co-creating value with enterprises. Customers are being encouraged to give reviews, recommend treatments, share their observations, suggestions, and posts providing information on the latest offer with their friends.

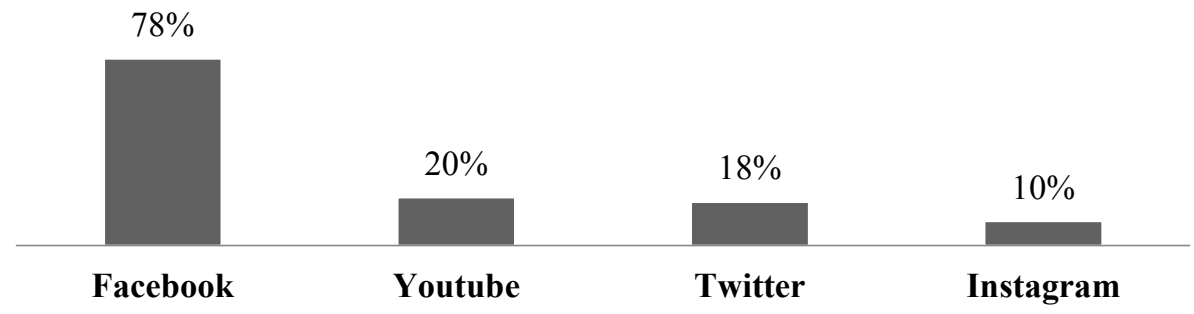

Figure 2. The utilization of social media platforms by health resort enterprises in Poland. Source: Authors' evaluation.

It should also be strongly emphasized that health resort enterprises (via representatives responsible for running social media profiles) are proactive in responding to customers' comments or questions; in $100 \%$ of Facebook fan pages, the enterprise responded to comments at least once.

\section{Cooperation platforms for value creation processes}

The variety of benefits and opportunities for value creation arising from cooperation might be observed in 'old' sectors like the health resorts sector (Kozarkiewicz, and Kabalska, 2017). The benefits comprise access to unassailable resources or organizational competences, synergies, mutual learning and knowledge exchange, lowering costs, as well as the occurrence of collaborative networked organizations and the tourism industry. In the health resort sector, there is a variety of cooperation forms and business partnerships: value shops, value-adding partnerships, value networks, clusters, business ecosystems, as well as strategic alliances (Kabalska, and Kozarkiewicz, 2016).

The results demonstrated the diversification of approaches to cooperation and collaboration mediums, though the pertinence of new communication channels is prominent. Health resorts advertently present their offer, not only through their own websites but also on various portals 
related to tourism, recreation, sanatorium treatment or hotel services, which serve as an additional source of information. While referencing the particular website, the customer is oftentimes offered a small benefit, in a form of the reduced price (when purchasing the offer). The detailed presentation of the Internet sources is displayed in Figure 3; Internet websites have been classified into three main groups: websites related to sanatorium treatments and resort tourism (1), portals offering accommodation information, hotel presentations and booking systems (2) and sources regarding medical specifics (3).

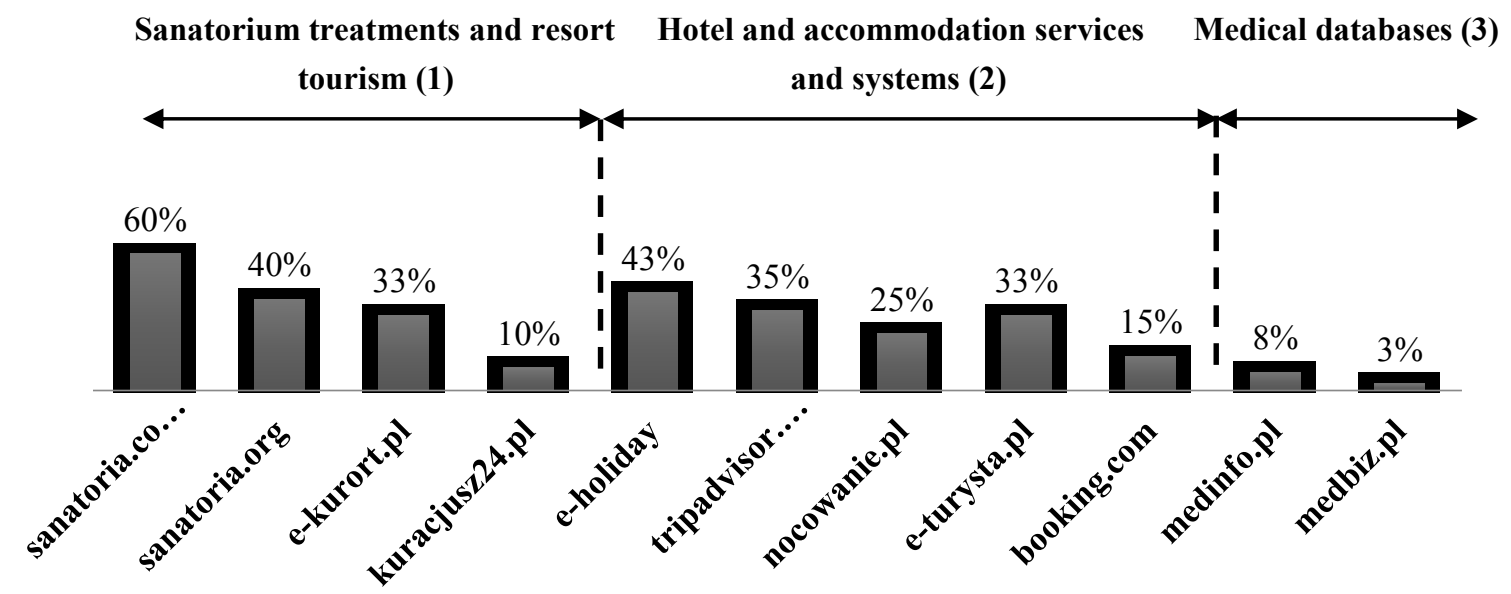

Figure 3. Websites and portals where resort's offer is presented. Source: Authors' evaluation.

As presented in Figure 3, the majority of health resort enterprises have their offer displayed on websites dedicated to sanatorium offers and treatments $(60 \%)$. Value is also co-created by websites concerning tourism and holiday planning (43\%). Subsequent results replicate this sequence: $40 \%$ for sanatorium-related sanatoria.org and $35 \%$ for tripadvisor.com.

\section{Discussion}

The conducted research could be described as an exploratory data analysis rather than field tests. The research on the impact of DT, not only on health resort operations but also on the broad-based approach to value-creation, is still insufficient and requires deepened and multisided analysis. Considering the research results, the following observations might be featured:

1. Health resort enterprises demonstrate different approaches to DT. The indication of these dissimilarities could be, for instance, the variance of resort businesses' websites: from very simple, concise mediums of communicating the overview, more elaborated pages, where contact forms or reservation systems are offered, to well-designed, userfriendly platforms where the latest technological solutions are presented (e.g. virtual walk-through or immersive video). 
2. A newsletter is a new form of communicating with customers, offered by nearly $25 \%$ of health resort companies from the research sample. However, almost $30 \%$ of the resort enterprises focus on emphasizing the importance of customers' opinions and recommendations, expressed through customers' reviews published on social media and/or the website. This is not a surprising phenomenon; co-creating value with customers is regarded as a new practice of value creation or a customer-centric innovation (Selden, and MacMillan, 2006).

3. Social media, especially Facebook, have a major role. Social media profiles that are professionally run, regularly updated with attractive content appear to be the universal key for establishing and maintaining relationships with customers. Despite assigning this element a fairly low rating in the conducted survey, health resort managers seem to notice the great potential in using new communication channels, not only for creating and maintaining customer relations but also opening opportunities and introducing their virtues to business partners.

4. In response to changing customer needs and expectations, growing competition and the emergence of new customer segments interested in a different offer, health resort enterprises also provide services related to broadly understood tourism, recreation, leisure or relaxation. Due to the wide range of services and variety of offers (as well as new customers, such as tourists, including foreigners), resort enterprises exert efforts to present their offer on various websites related to hospitality and medical services.

5. Owing to DT, the value-creation process becomes more elaborated; it engages various participants, such as resort businesses, dedicated portals, business partners and other entities (i.e. local governments, cultural institutions and business owners).

\section{Conclusions}

DT is a process where digital technologies create disruptions inducing strategic responses from organizations aimed at alterations in value creation. The discussions about DT are mostly oriented towards technological solutions and strategic changes, including business model innovations. One of the important issues is the performance of very traditional businesses under the pressures of new technologies. An interesting example in this context is the sector of Polish health resorts - undergoing the change from natural-resource-based enterprises to marketoriented and modern businesses. Here, the role of DT in the enhancement of value-creation processes seems to be underestimated. An important question is, for example, the importance of modern information systems, websites or social platforms confronted with substantial, protechnological activities undertaken by health resorts. 
It seems that the presented research could offer insights to different audiences, both from academic circles, who might be interested in understanding DT phenomenon in one real economic and social context and practitioners, who would be interested in innovations and new directions of the transformation in Polish health resorts.

There are some limitations of this research, resulting mostly from the small research sample or very limited editorial possibilities. A detailed comparative analysis of the content of websites and social media pages would offer a deeper understanding of the situation. However, performed studies were exploratory in nature and were rather descriptive, illustrating an interesting phenomenon. The study demonstrates the vast potential of in-depth research into the role of new technologies in the 'traditional' services sectors.

\section{References}

1. Berman, S.J. (2012). Digital transformation: opportunities to create new business models. Strategy \& Leadership, 40(2), 16-24.

2. Bertola, P., and Teunissen, J. (2018). Fashion 4.0. Innovating the fashion industry through digital transformation. Research Journal of Textile and Apparel, 22(4), 352-369.

3. Kabalska, A., and Kozarkiewicz, A. (2016). Konfiguracja wartości dla klienta w sektorze uzdrowiskowym w Polsce. Studia Ekonomiczne: Zeszyty Naukowe Wydziałowe Uniwersytetu Ekonomicznego w Katowicach, 299, 137-147.

4. Kozarkiewicz, A., and Kabalska, A. (2017). Kuracjusz i klient: ewolucja propozycji wartości w modelach biznesowych przedsiębiorstw uzdrowiskowych w Polsce. Marketing i Rynek, 10, 296-309.

5. Leung, X., Bai, B., and Stahura, K. (2015). Marketing effectiveness of social media in the hotel industry: A comparison of Facebook and Twitter. Journal of Hospitality and Tourism Research, 39(2), 147-169.

6. Osterwalder, A., and Pigneur, Y. (2010). Business model generation: A Handbook for Visionaries, Game Changers, and Challengers. Hoboken: Wiley.

7. O'Sullivan, E., and Rassel, G. (1995). Research methods for public administration. White Plains: Longman.

8. Paul, M.J., and Dredze, M. (2011). You Are What You Tweet: Analyzing Twitter for Public Health. ArtificialIntelligence, 38, 265-272.

9. Remane, G., Hanelt, A., Nickerson, R., and Kolbe, L. (2017). Discovering digital business models in traditional industries. Journal of Business Strategy, 38(2), 41-51.

10. Scott, S.V., and Orlikowski, W.J. (2012). Reconfiguring relations of accountability: Materialization of social media in the travel sector. Accounting, Organizations and Society, 37, 26-40. 
11. Sebastian, I., Ross, J., Beath, C., Mocker, M., Moloney, K., and Fonstad, N. (2017). How big old companies navigate digital transformation. MIS Quarterly Executive. September, 197-213.

12. Selden, L., and MacMillan, I.C. (2006). Manage Customer-Centric Innovation Systematically. Harvard Business Review, 84(4), 108-116.

13. Szromek, A., and Pytel, S. (2014). Sprawność obsługi internetowej polskich przedsiębiorstw uzdrowiskowych. Zeszyty Naukowe Politechniki Śląskiej, Seria: Organizacja i Zarzadzanie, 71, 271-280.

14. Warner, K.S., and Wäger, M. (2019). Building dynamic capabilities for digital transformation: An ongoing process of strategic renewal. Long Range Planning, 52(3), 326-349.

15. Vial, G. (2019). Understanding digital transformation: A review and a research agenda. The Journal of Strategic Information Systems, 28, 118-144. 